九州大学学術情報リポジトリ

Kyushu University Institutional Repository

\title{
Some hippolytid shrimps living in coral reefs of the West Pacific
}

Miyake, Sadayoshi

Zoological Laboratory, Department of Agriculture, Kyushu University

Hayashi, Ken-Ichi

Zoological Laboratory, Department of Agriculture, Kyushu University

https://doi.org/10.5109/22752

出版情報：九州大学大学院農学研究院紀要. 14 (1)，pp.143-160，1966-06. Kyushu University バージョン：

権利関係 : 
Journal of the Faculty of Agriculture, Kyushu University, Vol. 14, No. 1 June 30, 1966

\title{
Some hippolytid shrimps living in coral reefs of the West Pacific*
}

\author{
Sadayoshi Mryake and Ken-Ichi HayASHI
}

The present paper reports on some notes and descriptions of the hippolytid shrimps found chiefly in the coral reefs of Amami-oshima, north of the Ryukyu Islands, and of the Palau Islands. The materials dealt here are referable to six species belonging to three genera of the family Hippolytidae. Holthuis (1953) published the enumeration lists of the decapod and stomatopod Crustacea from the Pacific coral islands, and described the following four species, Saron marmoratus (Olivier), S. neglectus de Man, Thor maldivensis Borradaile and $T$. paschalis (Heller). Among these the first three species are treated herewith. Three others are identified with $T$. amboinensis (de Man), Thor sp. and Lysmata dentata (de Haan) respectively.

The examination of the present material will emphasize the differences of the morphological feature and colour pattern, and may broaden and enrich the knowledge of the natural communities in the corals.

\section{Saron marmoratus (Olivier, 1811)}

(Figs. 1 and $3, \mathrm{a}-\mathrm{c}$ )

Hippolyte gibbosus: Dana, 1852, $565 ; 1855$, pl. 36 fig. 4, a-e.

Hippolyte hemprichii: Heller, 1862, 275, pl. 3 fig. 23.

Hippolyte marmorata: de Man, 1888, 533; Ortmann, 1890, 497, pl. 36 fig. 18.

Saron gibberosus: Thallwitz, 1891, 100; de Man, 1902, 852, pl. 26 fig. 57; Parisi, 1919, 74 .

Saron marmoratus: Borradaile, 1898, 1009; Coutière, 1910, 1263; Kemp, 1914, 84; Kemp, 1916, 385; Kubo, 1940, 80, figs. 5, 6; Holthuis, 1947, 25 ;† Barnard, 1950, 688, fig. 128a; Holthuis, 1953, 52.

Spirontocaris gibberosa: Balss, 1914, 46.

\footnotetext{
* Contributions from the Zoological Laboratory, Faculty of Agriculture, Kyushu University, No. 348.

$\uparrow$ The rest of the synonymy of this species will be found in his monograph.
} 


\section{Material examined:}

4 ovig. 우, Zoological Laboratory, Kyushu University (ZLKU) Cat. No. 1340, Ishigaki-jima, June 3-27, 1933, H. Ohshima, H. Ikeda and S. Miyake leg.

11 호, 2 ovig. 우우, ZLKU Cat. No. 2453, aUgulpelú Reef, Palau Islands $\left(7^{\circ} 17^{\prime} 20^{\prime \prime}\right.$ N., $134^{\circ} 32^{\prime}$ E.), May 5, 1939, S. Miyake leg.

1 ô, ZLKU Cat. No. 3289, Ngadarák Reef, Palau Islands $\left(7^{\circ} 17^{\prime} 30^{\prime \prime}\right.$ N., $134^{\circ} 28^{\prime} 30^{\prime \prime}$ E.), May 22, 1939, S. Miyake leg.

1 ŝ, ZLKU Cat. No. 1386, Palau Islands, date uncertain (during March to August 1939), S. Miyake leg.

1 ovig. ㅇ, ZLKU Cat. No. 3270, Kume-jima, March 4, 1960, H. Minei leg.

1 ô, ZLKU Cat. No. 3271, Nagusuku, Okinawa-jima, April 31, 1961, H. Minei leg.

1 s, ZLKU Cat. No. 3272, Gushichan, Okinawa-jima, July 3, 1962, H. Minei leg.

1 ô, 3 ovig. 우, 8 juv., ZLKU Cat. Nos. 2437 and 3146, Kasari, Amamioshima, August 5-6, 1964, K. Baba leg.

2 ovig. 우, 7 juv., ZLKU Cat. No. 3156, Kasari, Amami-oshima, July 26, and August 1, 1965, K. Baba leg.

Description: The rostrum is provided with seven teeth on the upper border, the proximal three of which stand upon the carapace, and with five to eight teeth on the lower (30 specimens with six). The rostrum is longer than the carapace in both sexes; the male has the rostrum even longer than that of the female. The antero-lateral margins of the carapace are furnished with three spines, namely welldeveloped antennal, small branchiostegal and feeble pterygostomian. The branchiostegal spine is situated much nearer to the middle point of the antero-lateral margin than to the pterygostomian spine. There are several tufts of plumose hairs; those studded with one row on the dorsal carina of the carapace and two rows along the dorsal medial line of the abdomen are long and dense in this species (Fig. 1). The tooth on the dorsal side of the third segment of the antennular peduncle is horizontal, not upstanding forward as in $S$. neglectus de Man.

Two large males (Cat. No. 2453, $9.8 \mathrm{~mm}$ in carapace length; Cat. No. $3271,7.1 \mathrm{~mm}$ ) show a well-represented secondary sexual character with the third maxilliped and first pereiopod; the length of the ultimate segment of the third maxilliped measures $16.4 \mathrm{~mm}$ and $14.3 \mathrm{~mm}$ respectively. In the smaller individual mentioned above the first pereiopod is well developed and symmetrical, measuring $19.4 \mathrm{~mm}$ long from the tip of the dactylus to posterior border of the merus in the dorsal 
median line; the length of the dactylus relative to those of other segments is greatest in its development in comparison with that of an ovigerous female, being measured about three and four-fifths times as

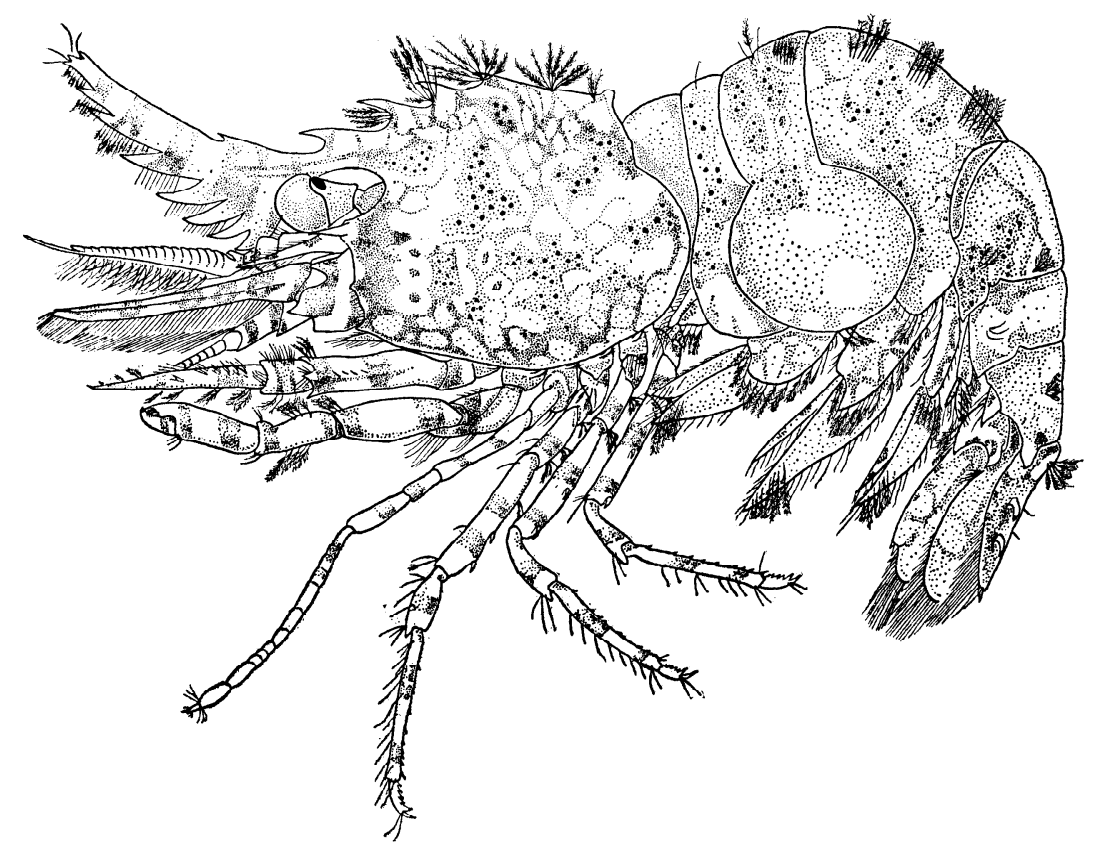

Fig. 1. Saron marmoratus (Olivier), female, showing colour pattern. $\times 3.3$.

long as that of the latter; the propodus is also well developed, about two times as long as that of the ovigerous female and is equal to the length of the merus; the carpus is equal to the dectylus in length (Fig. 3, a). In the larger one, however, the first pereiopod is not so much developed as in the smaller, and is more or less related to that of the female in its length and feature.

The second pereiopod in both sexes is slender and the cutting edge of the dactylus is smooth without serration; the carpus is subdivided into 9 to 13 (usually 10 or 11) joints on either side, and the merus is composed of two joints except for only one specimen (Cat. No. 1343) with one joint from Ishigaki-jima. The third, fourth and fifth pereiopods are equally armed with two well-visible spines on the subterminal portion of the merus.

In the male the thoracic sterna which correspond to the second to fifth pereiopods have a pair of upstanding spines, the posteriormost 
(on fifth pereiopod) of which is enlarged and fused with each other at the base being strongly bifurcate at the tip, whereas in an ovigerous female these spines are subject to variation in some extent; viz., the spines of the second sternum are transformed into a tuft of hairs, but spines are absent on the third, and those on the fourth are entirely modified and reformed to large plates, bending backward underneath the fifth spines, which change into a thin bifurcation with broad base.

Each of the first to third abdominal sterna in the male is also armed with a pair of upstanding spines, but on the fourth to sixth there is one spine at the middle. On the second pleopod there is an appendix interna arising at the middle point of the inner margin of the endopod, which is strongly developed, exceeding the tip of the endopod.

In the ovigerous female, on the other hand, all the sterna are unarmed without spine except for the last one. An appendix interna is present on the endopods of the second, third and fourth pleopods; those on the second and third are tiny and provided with some rows of the coupling hooks at the inner margin (Fig. 3, b), and that on the fourth is well developed, one-fourth times the length of the endopod, and is provided with similar hooks along the whole coupling margin so as to close firmly the incubatory pouch by zipping the hooks of large right and left endopods (Fig. 3, c).

The coloration when fresh was dark mottled brown tint as mentioned by Kemp (1916): "On close inspection the colouration of living specimens is very wonderful, resembling that of a rich Turkey carpet. At a casual glance, however, the animal is dull in tone and ......"

Distribution: This species spreads over the whole Indo-West-Pacific region, from the Hawaii, Marquesas and Tahiti Islands, southward to Australia and westward to the Malay Archipelago and across the tropical Indian Ocean to the Red Sea and the east coast of Africa. In southern Japan Balss reported from Satsuma [Kagoshima Prefecture] and Parisi (1919) from Iriomote, Yaeyama Islands.

Saron neglectus de Man, 1902

(Figs. 2 and $3, \mathrm{~d}-\mathrm{f}$ )

Hippolyte gibberosa: Ortmann, 1890, 497.

Saron neglectus de Man, 1902, 854, pl. 26 fig. 58; Coutière, 1910, 1263 ; Kemp, 1914,

87 ; Borradaile, 1917, 401; Holthuis, 1947, 30; Holthuis, 1953, 52 ; Holthuis, 1958,

32.

Material examined:

1 s., ZLKU Cat. No. 2158, Tosa-shimizu, Kochi Pref., 3-5 fms, date unknown (received on October 24, 1964), K. Sakai leg. 
1 ŝ, 1 ovig. ㅇ, 32 juv., ZLKU Cat. Nos. 2439 and 3165, Kasari, Amamioshima, August 5-6, 1964, K. Baba leg.

2 송, 2 ovig. 우우, 1 우, 17 juv., ZLKU Cat. No. 3196, Kasari, Amamioshima, July 29, 31 and August 1, 1965, K. Baba leg.

Description: This species is closely related to $S$. marmoratus (Olivier), especially in its general body form, but differs from the latter in the following characters. (Fig. 2).

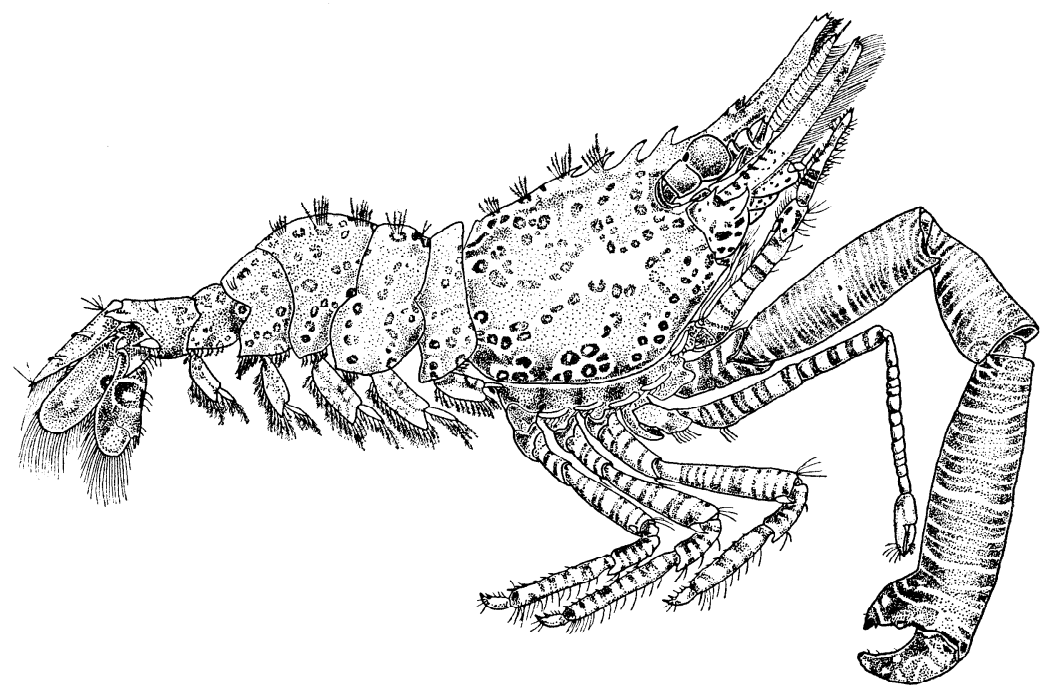

Fig. 2. Saron neglectus de Man, male with large first pereiopod, showing colour pattern. 2.8 .

The rostrum is provided with seven teeth on the upper border and three to six teeth (mostly five) on the lower. The anterior part of the carapace is armed with three spines, namely, antennal, branchiostegal and pterygostomian. The pterygostomian spine is sharply pointed, and the distance between the branchiostegal and pterygostomian spines is slightly shorter than that in S. marmoratus. The hinder edge of the orbit is double in lateral view even in the youngest specimens. The plumose hairs are growing on the upper and lower teeth, and also on a few portions of the carapace and abdominal somites as in the case of the relative, in which the hairs are longer and denser than those in this species. The tooth on the dorsal side of the third segment of the antennular peduncle is conspicuous and upstanding forward.

The third maxilliped is normal, never extending to the rostral apex in our specimens. In the adult males a secondary sexual character is more or less represented by asymmetrical growth of the first pereio- 
pod: One male from Amami-oshima (Cat. No. 3208, $6.5 \mathrm{~mm}$ in carapace length) is an example having the first pereiopod highly developed and covered by numerous granules; the length of the right first pereiopod (left is missing) measures $27.2 \mathrm{~mm}$ long from tip of the dactylus to posterior border of the merus, and the proportional length of the propodus to other segments is the greatest, measuring about five times as long as that of an ovigerous female. The propodus is rather longer than the length of the merus (Fig. 3, d). Another material from the same locality (Cat. No. $2441,6.6 \mathrm{~mm}$ ) has a similar tendency in the growth of the first pereiopod being appearently asymmetrical, the left longer than the right. A third from the same locality (Cat. No. 3196, $6.5 \mathrm{~mm}$ ) shows less development that might have been caused from a parasitic bopyrid in the gill chamber. A fourth from Tosa-shimizu (Cat. No. 2158, $4.6 \mathrm{~mm}$ ) has a malformed first pereiopod, the right being short and not chelate, instead of having the left cheliped with normal but small size. All the female specimens examined here do not show these characteristics of the first pereiopod as in the male mentioned.

The dactylus of the second pereiopod is provided with minute teeth along the cutting edge; the carpus is subdivided into 9 to 13 joints (usually 11); the merus is composed of only one joint. The following three pereiopods show similar features and each of them is provided with only one spine on the subterminal portion of the merus without exception.

In the male the spines of the thoracic sterna are similar to those of S. marmoratus in their features, while in the female the spines do not appear on the second and third thoracic sterna and are wholly modified into the low processes on the fourth, but on the fifth the spines are developed in almost similar features to those in $S$. marmoratus, except for the blunt lobe in this species in most case. The spines of the abdominal sterna in both sexes and the appendix interna in the male are nearly same as in the relative in the degree of development. The appendix interna in the female of this species, however, is lower than that of S. marmoratus (Fig. 3, e), and it is remarkably low and long on the fourth pleopod, bearing the coupling hooks near proximal half of the inner margin of the endopod (Fig. 3, f).

The colour of the living animal shows mottled pattern; the entire carapace and abdominal somites including the antennal peduncle and antennal scale are mottled with many dark brown spots fringed with pale ycllow on a ground colour of yellowish-brown. The rostrum is green with a few small pale yellow spots. The third maxilliped and succeeding five pereiopods have the colour pattern of some deep brownish-green stripes and streaks on the ground colour of yellowish-green. However, in the large first pereiopod of males this mode of the pattern become 


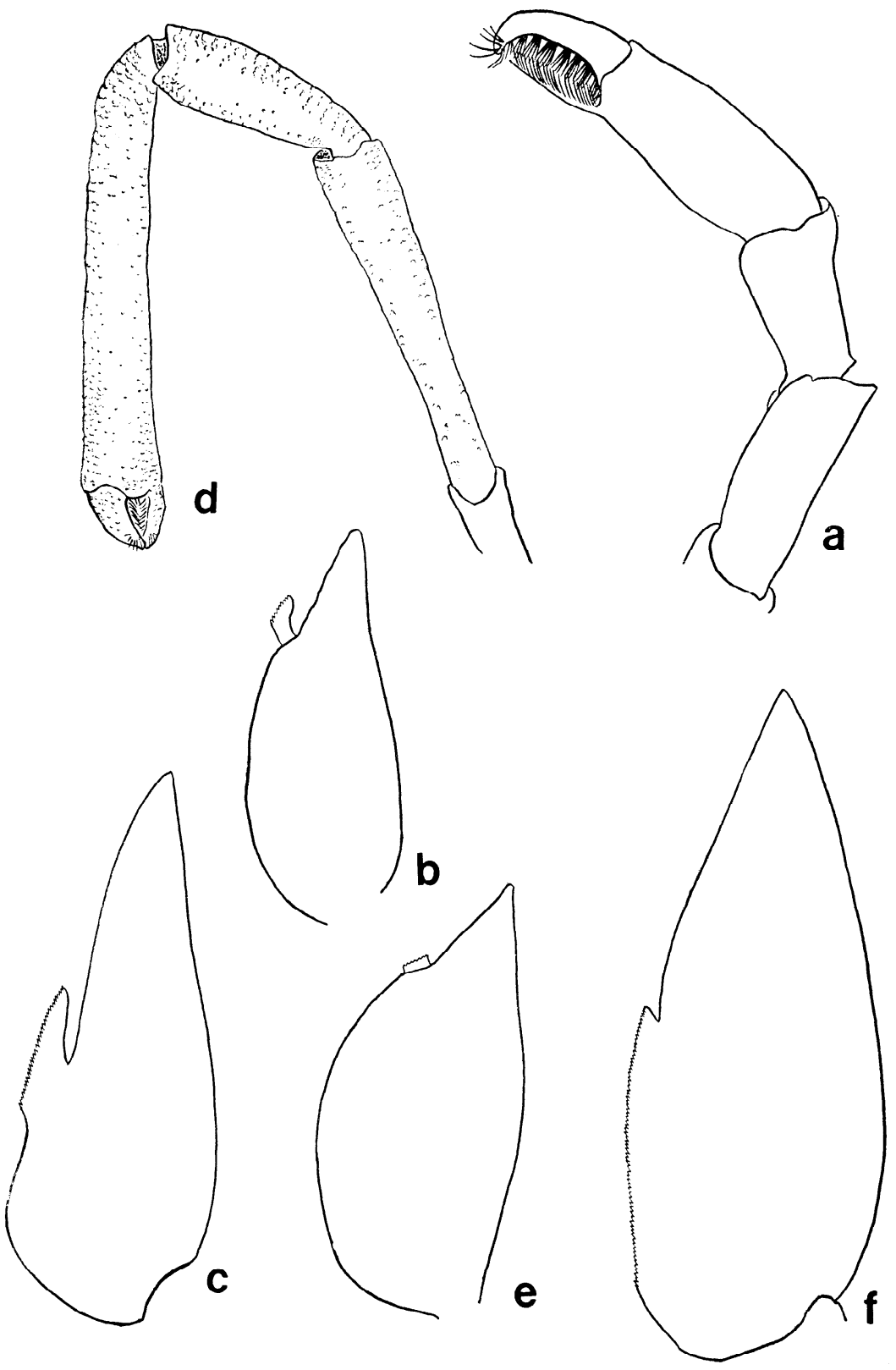

Fig. 3. Saron marmoratus (Olivier). a, first pereiopod of male; b, second pleopod of female with appendix interna; $c$, fourth pleopod of female with appendix interna. Saron negleclus de Man. d, first pereiopod of male; e, second pleopod of female with appendix interna; $f$, fourth pleopod of female with appendix interna. 
reversible by having wider dark bands, and moreover, the tips of both movable and immovable fingers are darker. The uropod is ornamented with a large circular patch; the exopod has a complete ring; the endopod has fragmental pattern with pale yellow in the center and bluish-black along the margin, and the whole is again surrounded by bright brown.

Distribution: This species seems to have same range of the distribution as in $S$. marmoratus so far as known to the authors. In southern Japan Ortmann (1890) and de Man (1902) recorded from Kagoshima. All of the specimens which belong to the genus Saron collected from Amami-oshima have been found on the branches of the dcad corals, and they were invariably collected together with some galatheids.

\section{Thor maldivensis Borradaile, 1915}

(Figș. 4 and 8, a)

Thor maldivensis Borradaile, 1915, 208 ; Kemp, 1916, 391; Borradaile, 1917, 401, pl. 58 fig. 6; Holthuis, 1947, 48; Holthuis, 1953, 53.

\section{Material examined:}

1 ovig. +, ZLKU Cat. No. 3218, Kasari, Amami-oshima, August 5, 1964, K. Baba leg.

Description: A single ovigerous female treated herein is only 11 $\mathrm{mm}$ in total length. The rostrum is very short with the apex bent slightly downward, not extending to the distal end of the antennular peduncle. Four teeth are present on the dorsal border of the rostrum; the first tooth is situated just above the supraorbital spine, and the foremost is near the apex, which, therefore, shows a bifid appearance. The lower border is rather concave without tooth. The carapace bears two spines, e.g. well-developed supraorbital and small antennal (Fig. 4).

The eye is large, extending beyond the tip of the rostrum; the cornea is rather shorter than the stalk. The round ocular spot is distinct in contact with cornea.

The basal segment of the antennular peduncle is long and armed with stylocerite, which bears a small erect spinule near the proximal end of the outer margin; the second peduncular segment is very short with a sharp tooth on the lateral side of the anterior margin; on the top of the third there is a triangular tooth. The outer antennular flagellum is well thickened and setose in the proximal nine joints. The inner flagellum is threadlike and subequal in length to the outer one. The antennal scale is flat and broad, and the spine on the outer margin is falling short of the distal tip of the lamellar part. 
The mandible is provided with both molar and incisor processes but without a palp; the edge of the molar is hemmed with minute teeth; the incisor process is well developed with five teeth along the distal margin of the apex (Fig. 8, a). The third maxilliped extends to the antennal scale; the ultimate segment is armed with six bristles at the tip and three and half as long as the penultimate; the exopod is long, almost reaching the distal margin of the antepenultimate.

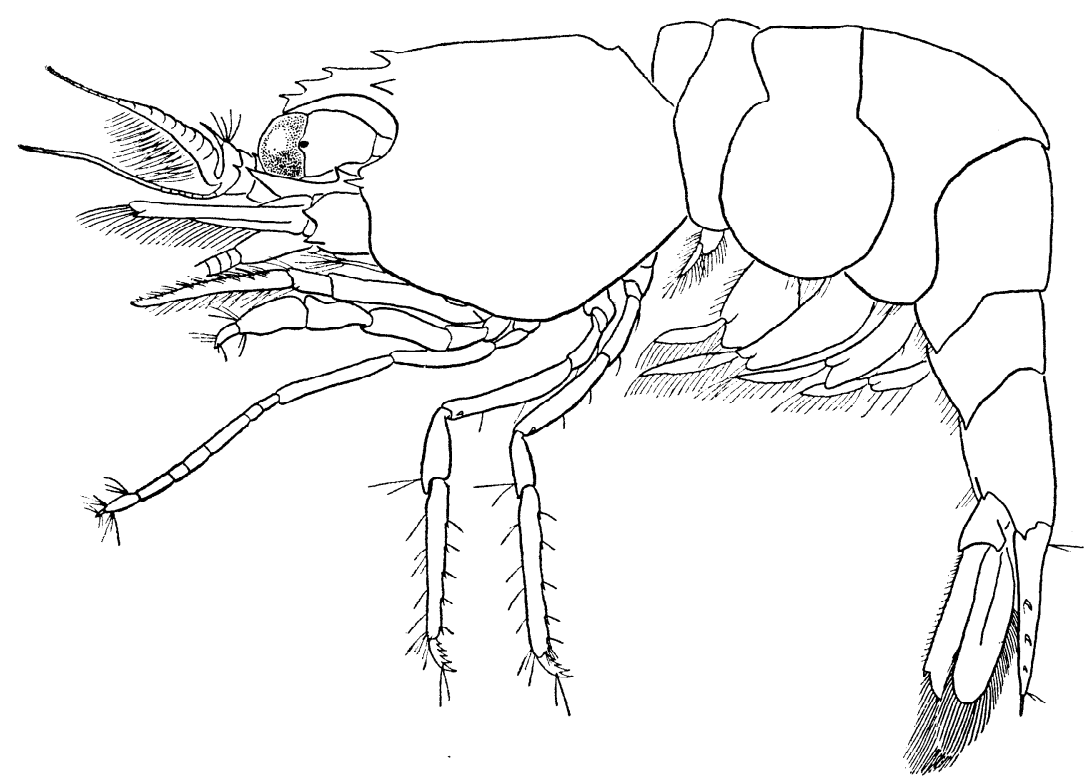

Fig. 4. Thor maldivensis Borradaile, female. 13 .

The first pereiopod is rather stout and extends as far as the distal end of the antennular peduncle. The second pereiopod is slender and exceeds the distal tip of the antennal scale; the carpus is subdivided into six joints, of which the third is the longest of all and the second is the shortest in length. The third pereiopod is missing in our specimen, and the fourth and fifth ones are similar in features, having a minute spine on the subterminal portion of the merus. The telson is a little shorter than the uropod, and has three pairs of spines on the dorsal surface. Every one of the endopods of the second, third, fourth and fifth pleopods is provided with a small appendix interna.

Distribution: This species is recorded here as new to the fauna of Japan though known from several localities in the Indo-West-Paciflc region. 
(Figs. 5, 6 and 8, b)

Hippolyte paschalis? de Man, 1888, 534.

Hippolyte amboinensis de Man, 1888, 535.

Thor discosomatis Kemp, 1916, 388, fig. 1, pl. 36 fig. 1; Kemp, 1925, 330.

Thor amboinensis: Holthuis, 1947, 50.

\section{Material examined:}

1 ovig. ㅇ, ZLKU Cat. No. 1347, Ishigaki-jima, July 3-27, 1933, H. Ohshima, H. Ikeda and S. Miyake leg.

1 o, ZLKU Cat. No. 1963, Ishigaki-jima, June 25, 1934, H. Ohshima leg. 2 ŝิ, 1 ovig. 우 ZLKU Cat. No. 1969, locality and date uncertain (Palau or Yaeyama Islands), S. Miyake leg.

2 ovig. 우우, ZLKU Cat. No. 2954, Ngadarák Reef, Palau Islands $\left(7^{\circ} 17^{\prime}\right.$ $30^{\prime \prime}$ N., $134^{\circ} 28^{\prime} 30^{\prime \prime}$ E.), June 18, 1939, S. Miyake leg.

Description: The specimens range from $14 \mathrm{~mm}$ to $17 \mathrm{~mm}$ in total

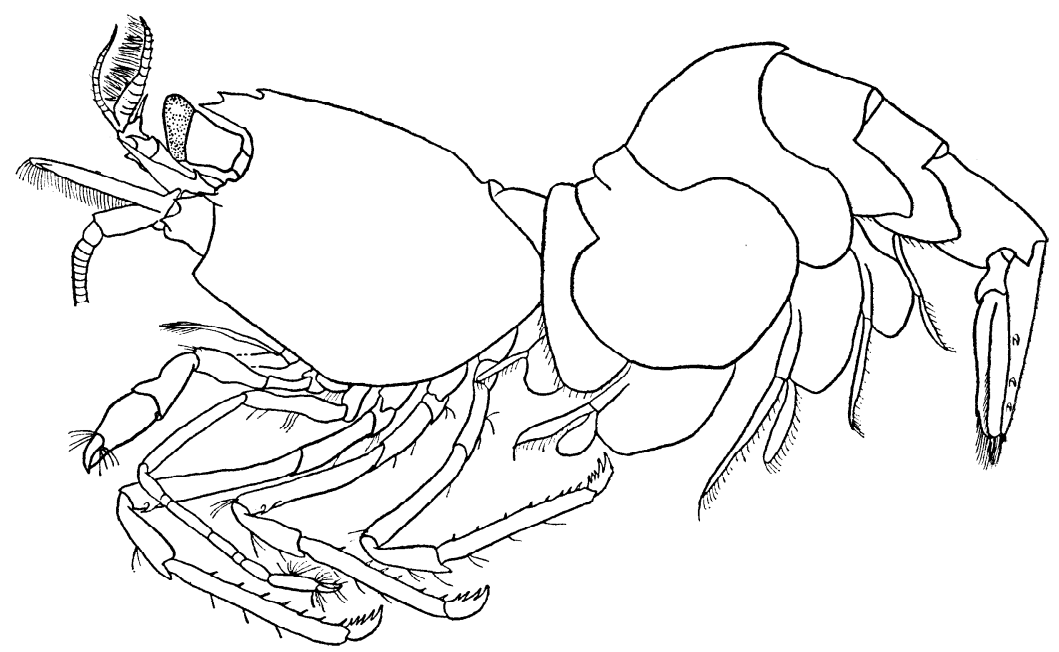

Fig. 5. Thor amboinensis (de Man), female. 7.7 .

length. The rostrum is very short with two to four teeth on the upper border, but smooth without teeth on the lower; the apex is generally pointed, except for one specimen (Cat. No 1971) having a bifid appearance. The carapace is provided with a small antennal spine, but is absent from the supraorbital and pterygostomian spines (Fig. 5).

The eye is cylindrical form; the eyestalk is longer than the cornea. Both antennule and antenna show the same features, armatures and 
proportional lengths as those in $T$. maldivensis. The mandible has the incisor process, which bears five teeth along the distal margin of the apex, but it has not the palp (Fig. 8, b). The third maxilliped is long, reaching to the distal tip of the antennal scale.

The first pereiopod is short and stout. The carpus of the second pereiopod is subdivided into six joints. There is only one spine on the terminal portion of each merus of the third and fourth pereiopods, and the fifth is not armed with a small spine on the same portion in most specimens, but exceptionally one from Ishigaki-jima (Cat. No. 1347) has a small spine.

The third abdominal segment is prominent, and its dorsal ending is produced round. The pleura in both of the fourth and fifth segments are terminated posteriorly in obtuse point. The telson is armed with three pairs of spines on the dorsal surface, and with four pairs on the apex.

In the male there are both appendix masculina and appendix interna on the endopod of the second pleopod; both of these are shorter than the endopod, but the appendix masculina is one and fourfifths times as long as the appendix interna. The third and fourth pleopods have appendix interna only which is rather shorter than that of the second endopod. On the other hand, in the ovigerous female each of the second, third, fourth and fifth pleopods has a tiny appendix interna.

Living colour of the body and legs is dcep yellowish-brown and translucent (Fig. 6). The carapace is ornamented with large patches which are very light purple in the center with a broad margin of whitish-yellow, and the whole is again narrowly circumscribed by a deep blue being confluent in the median line. The pleura of second abdominal somite is ornamented with a circular patch, the fourth somite with a broad transverse

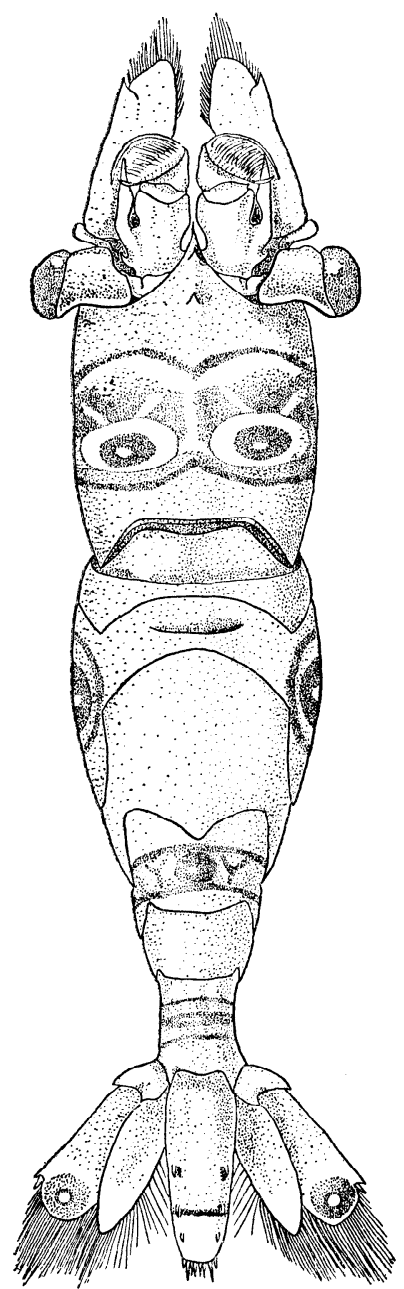

Fig. 6. Thor amboincnsis (de Man), male, showing colour pattern in dorsal view. band, and the sixth with complete ring, each of these patches has 
similar pattern to that on the carapace. The apex of the telson is margined by pale green as in the endopod of uropod, but distal part of the exopod is circumscribed by reddish-brown. The antennular flagellum is pure green distally, and the upper side of the eyestalk is pale green.

Distribution: The species has been recorded from several coral reefs of the Indian and tropical West-Pacific Oceans, being seldom seen to live in sea-anemones. Mostly, some small fishes, such as Actinicola percula (Lacèpéde), and also a pair of decapods, Periclimenes (Harpilius) brevicarpalis (Schenkel) and Neopetrolisthes ohshimai Miyake are usually found to live in tropical sea-anemones.

The specimens (Cat. Nos. 1963, 2954) from Ishigaki-jima and Palau Islands were found to be commensal with the giant sea-anemone, Stoichactis kenti (Haddon et Shackleton), measuring about $30 \mathrm{~cm}$ in diameter. Whether the other specimens treated here have been commensal with the sea-anemone or not is uncertain.

\section{Thor sp.}

(Figs. 7 and 8, c, d)

\section{Material examined:}

1 ㅇ, ZLKU Cat. No. 3219, Kasari, Amami-oshima, August 5, 1964, K. Baba leg.

Description: A tiny shrimp, only $11 \mathrm{~mm}$ in total length, is used here. The rostrum is armed with four teeth on the upper border, the first one is placed on the carapace behind the orbital notch, the anteriormost is situated near the rostral apex and it, therefore, makes a bifid appearance. The carapace is rather compressed. The antennal spine is acute and placed a short distance below the suborbital angle which is produced triangularly. The supraorbital spine is absent and the pterygostomian angle is round (Fig. 7).

The eye is large, extending beyond the rostral apex.

The antennular peduncle exceeds the rostral apex; the stylocerite of the basal peduncular segment bears a small erect spinule near the proximal end of the outer margin; the second peduncular segment is armed with a small tooth on the lateral side of the anterior margin, which extends as far as the distal apex of the stylocerite; the third segment is also armed with a broad movable tooth at the distal tip of the dorsal side.

The outer antennular flagellum is thickened with long setae growing on the proximal 11 joints of the flagellum. The antennal scale 
is very broad and the spine of the outer margin reaches to a short distance beyond the lamellar tip of the scale.

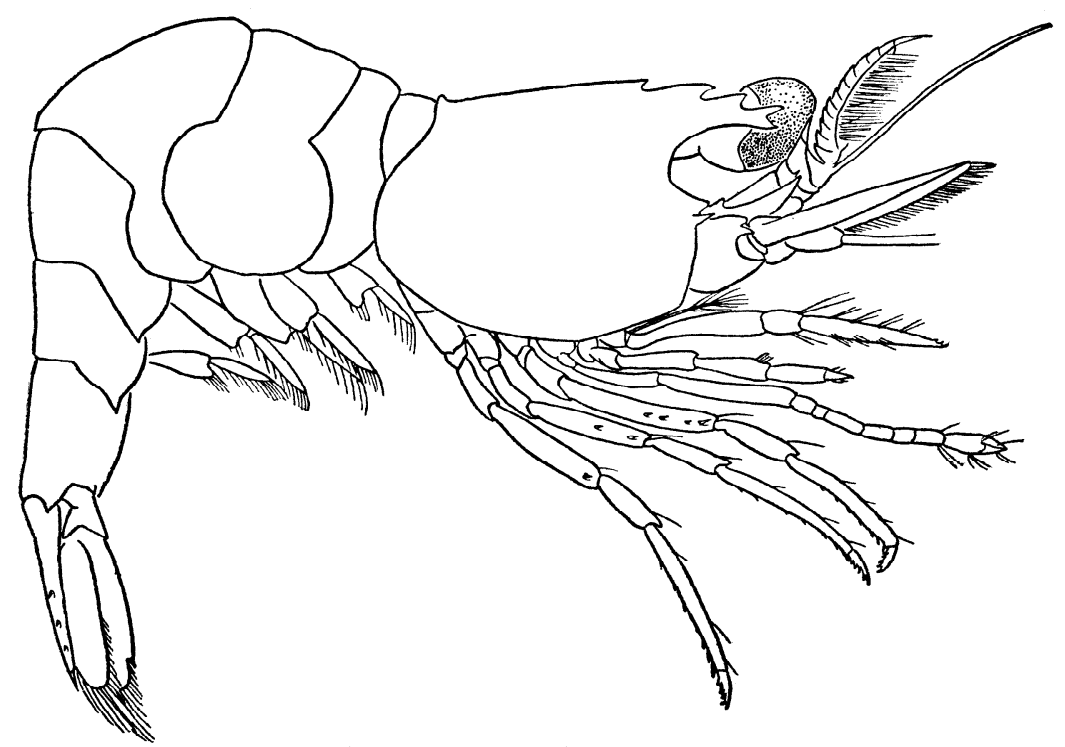

Fig. 7. Thor sp., female, right eye omitted. $\times 15.9$.

The mandible is composed of molar and incisor processes; the molar process bears numerous teeth, and the incisor one ends in eight teeth (Fig. 8, c). The third maxilliped which extends to the distal end of the antennal scale, is furnished with a long exopod; the ultimate segment is armed with four bristles at the tip.

The first pereiopod is slender, as large as the third maxilliped, and reaches about the middle point of the ultimate segment of the third maxilliped; the movable finger is one-third as long as the palm; the carpus and merus are subequal in length and are rather longer than the palm (Fig. 8,d). The second pereiopod is more slender and exceeds the bristles of the third maxilliped; the carpus is composed of six joints and their proportional lengths are the same as in T. maldivensis.

The following three pereiopods are equal and compressed; the merus of the third pereiopod is armed with four minute spines on the lateral side; the fourth pereiopod is armed with similar two spines on the distal half of the merus, and the fifth has only one spine on the subterminal portion of it.

On the dorsal surface of the telson there are three pairs of spines. The appendix interna is present on all the endopods of the pleopods with the exception of the first. 
Remarks: According to the excellent monograph of Holthuis (1947), this genus is composed of five species which are divided into two groups by the presence or absence of the supraorbital spine. The
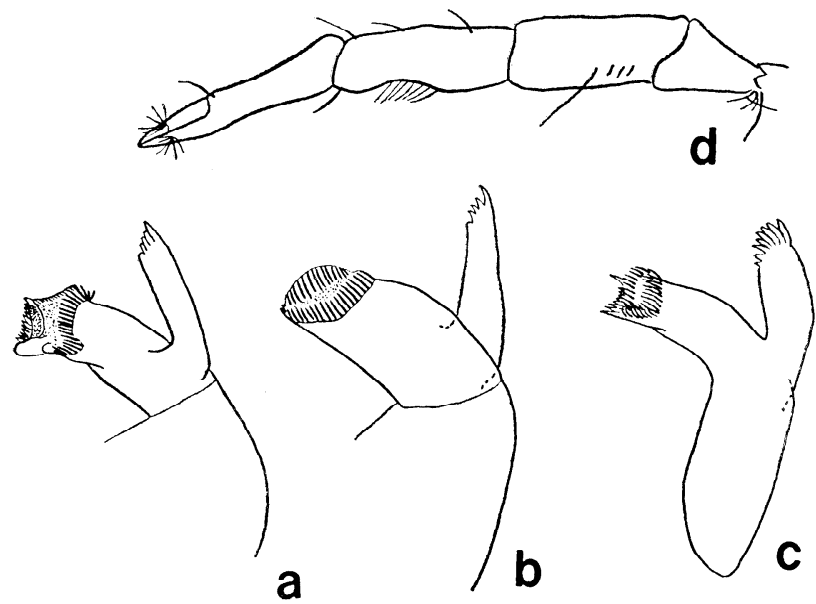

Fig. 8. Thor maldivensis Borradaile. a, mandible.

Thor amboinensis (de Man). b, mandible.

Thor sp. c, mandible; d, first pereiopod.

present species has no supraorbital spine, and therefore, differs sharply from the $T$. maldivensis, which has a strong supraorbital spine, and is included in the same group in company with the other three species, $T$. paschalis (Heller), T. intermedius Holthuis and T. amboinensis (de Man) from Indo-West-Pacific region. This species differs, however, from $T$. paschalis by the presence of an erect spinule of the stylocerite, which is absent in the latter, and is distinct from $T$. intermedius by the numbers of dorsal spines of the telson, in spite of the fact that the first pair of the pereiopod of this species is slender, rescmbling the figure of $T$. intermedius Holthuis (1947). And, this species is related to $T$. amboinensis in many respects, but the differences between these two species are in the following: According to Kemp (1925), Thor discosomatis ( $=T$. amboinensis) has two to four rostral teeth, of which the first one stands immediately above the hinder limit of the orbit; this material also has four rostral teeth, but the first one lies on the carapace behind the orbital notch and the very second one stands just immediately above the hinder limit of the orbit. Furthermore, the spines of each merus of the third and fourth pereiopods of this species is entirely unique having four and two respectively, instead of having one spine on both third 
and fourth of the other members and the teeth of the incisor process of the mandible are eight in this species but five teeth in the former two species mentioned above.

However, it would be better to defer to give a trivial name for this species until more sufficient materials became available though there are some noteworthy differences, as mentioned above, between the present species and the known ones.

\section{Lysmata dentata (de Haan, 1841)}

(Figs. 9 and 10, a, b)

Palacmon dentatus de Haan, 1841, pl. 45 fig. 13.

Lysmata seticaudata: de Haan, 1849, 176; de Man, 1888, 492; Calman, 1909, 706. Lysmata seticaudata ternatensis de Man, 1902, 846.

Lysmata affinis Borradaile, 1915, 209; Borradaile, 1917, 402.

Lysmata dentata: Holthuis, 1947, 64.

\section{Material examined:}

1 을 ZLKU Cat. No. 2594, Ngadarák Reef, Palau Islands $\left(7^{\circ} 17^{\prime} 30^{\prime \prime}\right.$ N., $134^{\circ} 28^{\prime} 30^{\prime \prime}$ E.), June 16, 1939, S. Miyake leg.

Description: The specimen is $24 \mathrm{~mm}$ in total length. The rostrum is straight and slightly exceeds one half of the second segment of the antennular peduncle. There are five dorsal teeth on the rostrum, of which the proximal three are placed on the

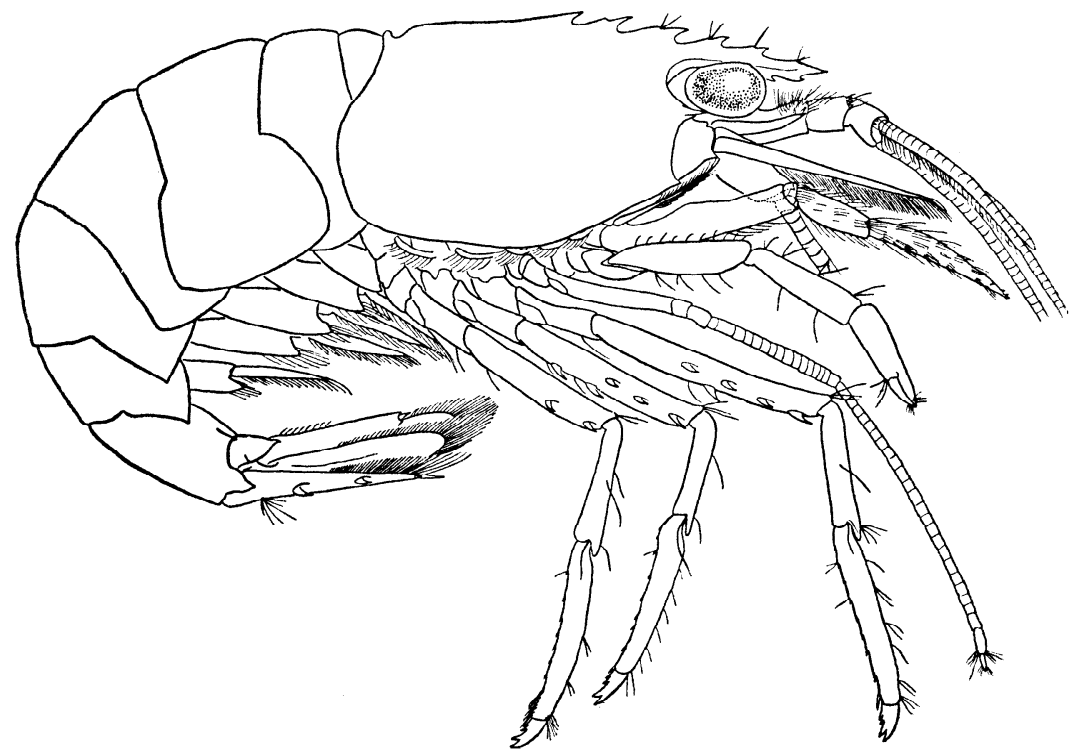

Fig. 9. Lysmata dentata (de Haan), female, ×5.3. 
carapace; furthermore, there is a small process with hairs on the middle point between the foremost tooth and rostral apex. The lower border of the rostrum bears two teeth which is smaller than those on the upper border and placed close to the apex in advance of the foremost upper rostral tooth. The carapace is provided with an acute antennal spine being continuous with the lower limit of the orbit, and the pterygostomian angle becomes a small but conspicuous spine (Fig. 9).

The eye is well developed and compressed; the cornea is as long as the stalk; no distinct ocular spot is present.

The antennular peduncle is long and reaches to two-thirds as long as the antennal scale; the basal segment is provided with a stylocerite which is sharply pointed and reaches to the end of the segment, and furnished with many hairs and some short spines on the antero-dorsal surface. Both of the second and third segments have also a few spines on each joint. The upper antennular flagellum is fused basally and thickened, composed of 10 joints, but it is biramous appically, of which the shorter one is composed of nine joints with setae.

The antennal scale is narrow, about three and a half times as long as wide; the outer margin is rather concave and terminates in a spine which extends slightly beyond the end of the lamellar portion (Fig. 10, a).

The third maxilliped which is provided with the conspicuous exopod and epipod, reaches by the distal half of the ultimate segment beyond the distal tip of the antennal scale.

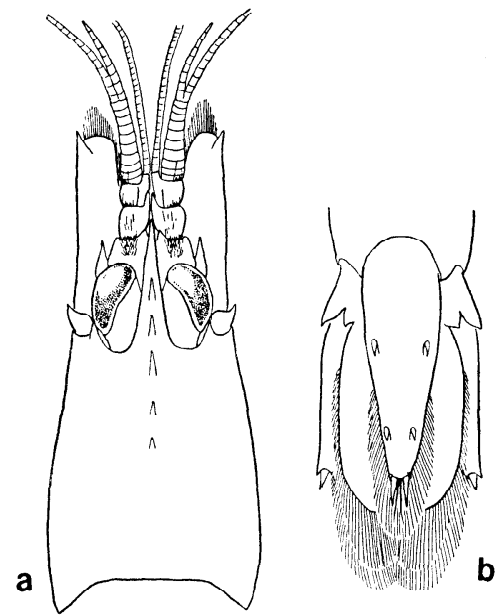

Fig. 10. Lysmata dentata (de Haan). a, carapace in dorsal view; $b$, telson in dorsal view.
The first pereiopod is as long as the third maxilliped; the carpus is subequal in length to the chela, the movable finger is about one-third the length of the palm. The second is very slender and extends beyond the antennal scale by the whole length of the chela and one half of the carpus; the ischium, merus and carpus are subdivided into four, fifteen, and twenty-three respectively.

The last three pereiopods are similar in features, and have about 10 spines increasing in size distally on the ventral side of the propodus and have three spines on the dactylus excluding the terminal claw. The third pereiopod reaches beyond the antennal scale by the length of 
the dactylus and propodus; on the merus there are four spines on the lateral side, and one (right leg) and two (left) on the ventral. The fourth pereiopod has three lateral spines and two ventral ones on the merus. There is an epipod on all the first to fourth pereiopods.

The dorsal endings of all the abdominal somites are round. The first somite is the smallest of all, the fifth is succeeding in length, and the second, third, fourth and sixth are longer than the formers and subequal in length. The pleura of the fourth and fifth abdominal somites arc pointed on the postero-lateral angle. The telson is one and a third times as long as the sixth somite but shorter than the uropod. There are two pairs of spines on the dorsal surface and a line of setae on the lateral margin of the telson, and its apex is also provided with two pairs of spines, of which inner one is longer, and a pair of long hairs (Fig. 10, b). The appendix interna is present on all the endopod of the pleopod except for the first one.

Distribution: The species is known from Japan and the Indian Ocean. This species was first recorded from Japan by de Haan (1841), and Ortmann (1890) gave the additional notes on the specimen. However, the definite locality in the original description is uncertain, and the locality given by the latter is nowhere to be found in Japan. The main habitat of the present species seems to be confined to the coral reefs.

\section{References}

Balss, H., 1914. Ostasiatische Decapoden II. Die Natantia und Reptantia. Abh. Bayer. Akad. Wiss., suppl. 2 (10): 1-101, figs. 1-50, pl. 1.

Barnard, K. H., 1950. Descriptive catalogue of South African decapod Crustacea. Ann. S. Afr. Mus., 38: 1-837, figs. 1-151.

Borradaile, L. A., 1898. On some crustaceans from the South Pacific. Part III. Macrura. Proc. zool. Soc. Lond., 1898: 1000-1015, pls. 63-65.

, 1915. Notes on carides. Ann. Mag. nat. Hist., (8) 15: 205-213.

, 1917. On carides from the western Indian Ocean. The Percy Sladen Trust Expedition to the Indian Ocean in 1905, under the leadership of Mr. J. Stanley Gardiner. Trans. Linn. Soc. Lond. Zool., (2) 17: 397-412, pls. 58, 59.

Calman, W. T., 1909. On decapod Crustacea from Christmas Island, collected by Dr. C. W. Andrews, F. R. S., F.Z.S. Proc. zool. Soc. Lond., 1909: 703-713, pl. 72.

Coutière, H., 1910. Sur les crevettes du genre Saron à mâles dimorphes. C. R. Acad. Sci. Paris, 150: 1263-1265.

Dana, J. D., 1852. Crustacea. United States exploring expedition during the years $1838,1839,1840,1841,1842$ under the command of Charles Wilkes, U.S.N., 13 (1): 1-1393. -, 1855. Atlas, 13:1-27, pls. 1-96. 
Haan, W. de, 1833-1850. Crustacea. In: Siebold, P. F. de, Fauna Japonica sive descriptio animalium, quae in itinere per Japoniam, jussu et auspiciis superiorum, qui summum in India Batava Imperium tenent, suscepto, annis 18231830 collegit, notis observationibus et adumbrationibus illustravit, $\mathrm{i}-\mathrm{xvii}, \mathrm{i}-\mathrm{xxxi}$, 1-244, pls. 1-55, A-Q, 1, 2.

Haswell, W. A., 1882. Catalogue of the Australian stalk- and sessile-eyed Crustacea, i-xxiv, 1-324, addenda, figs. 1-8, pls. 1-4.

Heller, C., 1862. Beiträge zur Crustaceen-Fauna des Rothen Meeres. Zweiter Theil. S. B. Akad. Wiss. Wien, 44 (1) : 241-295, pls. 1-3.

Holthuis, L. B., 1947. The Decapoda of the Siboga Expedition. Part IX: The Hippolytidae and Rhynchocinetidae collected by the Siboga and Snellius Expeditions with remarks on other species. Siboga Exped., Livr. 140, Monogr., 39 (a8): 1-100, figs. 1-15.

, 1953. Enumeration of the decapod and stomatopod Crustacea from Pacific coral islands. Atoll Res. Bull., 24: 1-66, 2 maps.

1958. Crustacea Decapoda from the northern Red Sea (Gulf of Aqaba and Sinai Peninsula). I. Macrura. Contributions to the knowledge of the Red Sea. No. 8. Bull. Sea Fisheries Res. Sta. Haifa, (17): 1-40, figs. 1-15.

Kemp, S., 1914. Notes on Crustacea Decapoda in the Indian Museum. V. Hippolytidae. Rec. Ind. Mus., 10: 81-129, pls. 1-7.

- 1916. Notes on Crustacea Decapoda in the Indian Museum. VII. Further notes on Hippolytidae. Rec. Ind. Mus., 12: 385-405, figs. 1-5, pl. 36.

1925. Notes on Crustacea Decapoda in the Indian Museum. XVII. On various Caridea. Rec. Ind. Mus., 27 : 249-343, figs. 1-24.

Kubo, I., 1940. On some littoral shrimps collected from Micronesia. J. Imp. Fish. Inst. Tokyo, 34: 77-99, figs. 1-15.

Miyake, S., 1942. Studies on the decapod crustaceans of Micronesia, III. Porcellanidae. Palao Trop. Biol. Stat. Stud., 2: 329-380, figs. 1-35, pl. 1.

Man, J. G. de, 1888. Bericht über die von Herrn Dr. J. Brock im indischen Archipel gesammelten Decapoden und Stomatopoden. Arch. Naturgesch., 53 (1): 215-600, pls. 7-22a.

, 1902. Die von Herrn Professor Kükenthal im Indischen Archipel gesammelten Dekapoden und Stomatopoden. In: Kükenthal, W., Ergebnisse einer zoologischen Forschungsreise in den Molukken und Borneo. Abh. Senckenb. naturf. Ges., 25: 467-929, pls. 19-27.

Nobili, G., 1906. Faune carcinologique de la Mer Rouge. Décapodes et Stomatopodes. Ann. Sci. nat., Zool., (9) 4: 1-347, figs. 1-12, pls. 1-11.

Ortmann, A., 1890. Die Decapoden-Krebse des Strassburger Museums, mit besonderer Berücksichtigung der von Herrn Dr. Döderlein bei Japan und bei den Liu-Kiu-Inseln gesammelten und z. Z. im Strassburger Museum aufbewahrten Formen. I. Theil. Zool. Jb. Syst., 5: 437-542, pls. 36, 37.

Parisi, B., 1919. I Decapodi giapponesi del Museo di Milano. VII. Natantia. Atti Soc. Ital. Sci. nat., 58: 59-99, pls. 3-6.

Rathbun, M. J., 1906. The Brachyura and Macrura of the Hawaiian Islands. Bull. U. S. Fish Comm., 23 (3): 827-930, figs. 1-79, pls. 3-24. 